\title{
IMPACT ANALYSIS OF NON-TARIFF MEASURES (NTM) ON INDONESIAN TUNA EXPORTS TO MAJOR DESTINATION COUNTRIES
}

\author{
Wiwiek Rindayati*1 and Oktavina Widya Kristriana*) \\ *) Departement of Economics, Faculty of Economics and Management, Bogor Agricuture Univesrsity \\ Agatis Street, Wing 4 Level 5, Bogor Agricuture Univesrsity Campus, Darmaga Bogor 16680
}

\begin{abstract}
Currently, international trade is hampered in both tariff and non-tariff measures. NonTariff Measures (NTMs) are likely applied by some major trading countries. The NTM policy mostly applies Sanitary and Phytosanitary (SPS) and Technical Barrier to Trade (TBT). Tuna commodity is one of Indonesian potential exports facing NTM barriers. Indonesia has exported its tuna to a number of major destinations including China, Japan, Thailand, United States, South Korea, Singapore, and Vietnam. This study aims to analyze the export performance and NTMs impact on the Indonesian tuna export commodity. The methods used included descriptive analysis through inventory approach (coverage ratio and frequency index) and regression analysis of gravity model panel data from the period of $2009-2013$ with the cross sectional data of the six major destination countries. The results show that United States as a country imposing the highest NTMs and frozen tuna is the most affected commodity group by NTM effects. The gravity model estimation results show that SPS and TBT affect tuna fish exports with positive coefficients of 0.011 and 0.015 respectively.
\end{abstract}

Keywords: gravity model, NTM, SPS, TBT, tuna fish

\begin{abstract}
Abstrak: Dewasa ini, perdagangan internasional mengalami hambatan baik tarif maupun non tarif. Negara-negara pelaku perdagangan cenderung memberlakukan tindakan non tarif (NTM). Kebijakan NTM yang paling banyak diberlakukan adalah Sanitary and Phitosanitary (SPS) dan Technical Barrier to Trade (TBT). Salah satu ekspor potensial Indonesia yang menghadapi hambatan NTM yaitu komoditi ikan tuna. Beberapa negara tujuan utama ekspor ikan tuna antara lain China, Japan, Thailand, The United States of America, South Korea, Singapore, dan Vietnam. Penelitian ini bertujuan menganalisis kinerja ekspor serta dampak NTM terhadap ekspor komoditi tuna Indonesia. Metode analisis secara deskriptif dengan pendekatan inventory (coverage ratio dan frequency index) dan analisis regresi data panel model gravity tahun 2009 - 2013 dengan cross section enam negara tujuan utama. Hasil pendekatan inventory menunjukkan The United States of America sebagai negara yang memberlakukan NTM terbanyak dan kelompok komoditi tuna yang paling banyak terkena NTM adalah tuna beku. Hasil estimasi model gravity menunjukkan SPS dan TBT berpengaruh nyata terhadap ekspor ikan tuna dengan koefisien positif sebesar 0.011 dan 0.015 .
\end{abstract}

Kata kunci: model gravity, NTM, SPS, TBT, ikan tuna

\footnotetext{
${ }^{1}$ Corresponding author:

Email: wiwiekrinda@yahoo.com
} 


\section{INTRODUCTION}

The export growth that has been promoted by international trade is hampered in both tariff and non-tariff measures. The tariffs are applied by World Trade Organization (WTO) in trading commodities all over the world, for both developed and developing countries. Various forms of tariff have been reduced through preference agreement of global trade. Nontariff measures have been applied by countries to protect their domestic producers in order to face import competitions with foreign products (Adi, 2007; Dahar, 2014; Fridhowati and Asmara, 2013; Deardorff and Stern, 1998; Disdier et al. 2008).

Currently, there are two trends in agricultural sector i.e. increase in the society consumption and problems on the originality of products and their compositions. Product safety and sustainable environment in production process are the things people will be more concerned about, and thus, it will make an impact on consumer's decision on agricultural product purchasing. In fact, their decision of purchasing is not only determined by them but also makes the important role for non-tariff measures (Boza, 2013; Mufidah, 2014; Renita, 2015).

"Non-tariff measures are generally defined by the measures other than ordinary customs tariff that can potentially give an economic impact on international trade of goods and changing in qualities, or prices, or both" (Fugazza, 2013; Nakakeeto, 2011; Staiger, 2012). They have been classified by UNCTAD into taxonomy from all relevant measures in international trade. Technically, the regulation is divided in two big categories, i.e. Ssanitary and Phytosanitary (SPS) and Technical Barrier to Trade (TBT). TBT measures refer to procedures for assessment of conformity with technical standards (including both requirements and conformity assessment procedure) and technical regulations. As in the case of TBT, SPS are measured to protect human or animal health and to limit any kind of disease from the importation of goods which may cause damage (Winchester, 2008; Bora et al. 2002; Disdier et al. 2008).

Indonesia has been incorporated in the World Trade Organization (WTO) and should open its domestic market for other countries and take every consequence of international trade. Every country has different policy for its international trade, and as the exporting country, Indonesia has to meet the requirements imposed by the importing country and maximize the export potency in order to encourage the national trade surplus.

Tuna is one of the ten potential commodities which play a role in encouraging Indonesian export. Based on the Ministry of Marine Affairs and Fisheries (2014), the growth of Indonesian fishery total production reached $3.53 \%$ in five years. This achievement was dominated by 269.5 tons of tuna and 381 tons of cakalang, making a note of tuna commodity as one of the great contributors to Indonesian export with USD 515 million. Table 1 shows the top three commodities for fisheries, such as shrimp, tuna, and crab exported to Japan, China, and United States as the major destination countries. The changing value of tuna commodity in 2011-2015 had a greater effect than others, with the value of $274.44 \%$ for China, and 28\% for Japan (Ministry of Marine Affairs and Fisheries, 2012).

China, Japan, Thailand, United States, South Korea, Singapore, and Vietnam are the major destination countries of Indonesian tuna exports. A bigger opportunity to encourage the volume of Indonesian tuna exports is given by the positive growth of the export and the market development of these countries. This opportunity has increased Indonesian bargaining position by its involvement in many world Associations for Tuna exports such as Western and Central Pacific Fisheries Commission/WCPFC, Commissions for the Conservation of Southern Bluefin Tuna/CCSBT and Indian Ocean Tuna Commission/ IOTC.

However, apart from the aim for applying the trade policy either to cope with market failure or as a protection, NTMs are expected to give a distortion effect on international trade. Limited access to the market is a new obstacle from the applied non-tariff measures by the importing countries in exchange to previous tariff policy (Fontagne et al. 2005; Tilova, 2012; Criveli and Groschl, 2012). The result of the study shows that even with no protection intention, NTM will increase the cost of trade and suppress the small producers in developing countries where law access and information on regulation are most likely hard to obtain. The trade cost can be increased by two ways. Firstly, by increasing the fix cost to accustom to product standards and regulations enforced by importing countries, and secondly, by performing conformity assessment procedures such as testing that will make an addition cost. 
Table 1. Fisheries volume and export value based on main commodities and destination countries of 2011-2012

\begin{tabular}{|c|c|c|c|c|c|c|}
\hline \multirow{4}{*}{ Countries } & \multicolumn{4}{|c|}{ Year } & \multirow{2}{*}{\multicolumn{2}{|c|}{$\begin{array}{c}\text { Change } \\
2011 / 2012\end{array}$}} \\
\hline & \multicolumn{2}{|c|}{2011} & \multicolumn{2}{|c|}{2012} & & \\
\hline & Volume & Value & Volume & Value & Volume & Value \\
\hline & (ton) & (USD 000) & (ton) & (USD 000) & $\%$ & $\%$ \\
\hline Japan & 123,830 & 806,060 & 118,732 & 842,118 & -4.12 & 4.47 \\
\hline Shrimp & 37,897 & 427,301 & 33,521 & 372,825 & -11.55 & -12.75 \\
\hline Tunas & 44,604 & 174,060 & 38,526 & 171,203 & -13.63 & -1.64 \\
\hline Crab & 1,149 & 12,892 & 383 & 2,763 & -66.67 & -78.57 \\
\hline United States & 126,931 & $1,070,484$ & 133,476 & $1,147,191$ & 5.16 & 7.17 \\
\hline Shrimp & 70,059 & 615,055 & 62,194 & 500,307 & -11.23 & -18.66 \\
\hline Tunas & 15,062 & 71,374 & 14,545 & 91,357 & -3.43 & 28.00 \\
\hline Crab & 10,016 & 198,319 & 4,976 & 91,236 & -50.32 & -54.00 \\
\hline China & 242397 & 220,998 & 295,486 & 284,664 & 21.90 & 28.81 \\
\hline Shrimp & 5920 & 25,432 & 6,136 & 39,804 & 3.65 & 56.51 \\
\hline Tunas & 711 & 1,518 & 6,640 & 5,684 & 833.90 & 274.44 \\
\hline Crab & 4379 & 16,033 & 6,950 & 41,622 & 58.71 & 159.60 \\
\hline Others & 563,858 & 963,626 & 594,304 & $1,133,95$ & 5.40 & 17.66 \\
\hline Shrimp & 27,527 & 97,652 & 43,858 & 279,302 & 59.33 & 186.02 \\
\hline Tunas & 51,263 & 154,159 & 113,645 & 358,242 & 121.69 & 132.39 \\
\hline Crab & 6,386 & 23,756 & 14,642 & 181,477 & 129.28 & 663.92 \\
\hline
\end{tabular}

Source: Ministry of Marine Affairs and Fisheries (2012)

Emerging issues regarding SPS and TBT that have been widely applied by the importing countries as a protection can be an obstacle to Indonesian tuna exports. The domestic Associations of Indonesian tuna such as Indonesian Longline Tuna Associations (ATLI), Indonesian Tuna Associations (ASTUIN), Pole and Line and Hand Line Fishery Associations (AP2HI), and Indonesian Commissions of Tuna (KTI) are taking an important note on tuna industry to face NTMs through improvements in quality standard and suppression of trade costs to meet the importing countries' standard (Bora et al. 2002; UNCTAD, 2013; Josling et al. 2004; Henson and Jaffe, 2014).

This study aims to analyze whether the impact of nontariff measures become obstacles or, on the contrary, create opportunities for Indonesian tuna exports, and establish a new implication policy to encourage the performance of Indonesian tuna exports.

\section{METHODS}

The data used in this research are the secondary timeseries data of the period of $2009-2013$ and the cross section data of the major destination countries including China, Japan, Thailand, the United States of America,
South Korea, Vietnam, Netherlands and Singapore. The commodities used based on HS 96 are grouped into six digits i.e. 030231, 030232, 030233, 030239, 030240, and 030250 for fresh tuna, 030341, 030342, 030343, and 030349 for the frozen tuna, and 160414 for processed tuna. The data came from various sources with the details in Table 2.

Cooperation between countries of international trade actors is conducted in order to expand market access and promote prosperity among WTO country members. One of international trade policies applied by WTO countries is Non- Tariff Measures (NTMs). This policy is applied as a form of protection against domestic producers in order to face import competition. Sanitary and Phytosanitary (SPS) and Technical Barriers to Trade (TBT) are most widely used in the implementation of NTMS.

One Indonesian potential export commodity that cannot be separated from the implementation of NTMs is tuna. The amount of production contributes substantially to the fisheries subsector and the growth of export value to several major destination countries. This is a great opportunity if it can be utilized maximally. The use of SPS and TBT which are widely applied to tuna commodities by major destination countries is 
intended to protect human, animal and plant life from various diseases, and they become technical regulations and conformity assessment procedures. Research framework in Figure 1.

The hypotheses in this research are as follows:

1. GDP per capita is positively related to the current value of export.

2. The population of importing coutries is positively associated with the exporting countries' current exports.

3. Economic distance negatively affects the trade relations among countries.

4. Real exchange rate is positively related with export flows among trade nations.

5. Applications of NTMs (SPS and TBT) by the importing countries give impacts to the export flows of the exporting coutries.

The inventory approach was used to analyze the applications of SPS and TBT by the importing countries in Indonesia tuna commodities. To analyze the impact of the application of SPS and TBT, regresson analysis of data panel approach gravity model was used. The results of this studies are the government's policy implications related to the development of tuna fish exports.

Descriptive analysis was used as a general overview of tuna export policy and NTMs applied by the destination countries. Inventory approach was used to analyze the applied NTMs with frequency index and coverage ratio as indicators. Frequency index was only used to measure the presence of NTMs and summarize the percentage of the products where NTMs are applied as explained by Fugazza (2013). Frequency index shows the percentage of import transaction involved in NTMs for exporting countries, whereas coverage ratio shows the percentage of trade subjects affected by NTMs and measures the importance of NTMs over all aspects. Both indicators are measures as follows:

$$
\begin{aligned}
& F_{i j t}=\left[\frac{\Sigma\left(D_{k t} M_{k T}\right)}{\Sigma M_{k T}}\right] \times 100 \\
& C_{i j t}=\left[\frac{\Sigma\left(D_{k t} V_{k \tau}\right)}{\Sigma V_{k T}}\right] \times 100
\end{aligned}
$$

Where: Fijt (Frequency index of exporting country $i$ to importing country $j$ on year $t(\%)$ ); Dkt (dummy variables which indicate the presence or absence of one or more NTMs on product k on year t); MkT (volume of product $\mathrm{k}$ with the total years of all imported volume);
Cijt (Coverage ratio exporting country i to importing country $\mathrm{j}$ on year $\mathrm{t}(\%)$ ); $\mathrm{VkT}$ (value of product $\mathrm{k}$ with the total years of all imported value); $j$ (importing country); i (exporting country); $\mathrm{k}$ (import product); $\mathrm{t}$ (year of the application of NTMs); T (total years of total imports to destination country).

The value of frequency index and coverage ratio is in the range of 1-100. Smaller number of frequency means fewer NTMs are imposed by the importing countries and bigger number means otherwise. The smaller number of coverage ratio means less product coverage affected by NTMs and vice versa with the bigger number. Gravity model is the tool to analyze the impact of NTMs on export using export value of Indonesian tuna to destination countries. The independent variables used included GDP per capita for importing countries, population of importing countries, economic distance, NTMs imposed by importing countries (SPS and TBT), and real exchange rate in period of 2009-2013. The model used in this study refers to gravity model by Fontagne et al. (2005), using coverage ratio approach as an independent variable. The model is formulated as follows:
$\operatorname{lnEX} \mathrm{ijt}_{\mathrm{jt}}=\alpha+\beta_{1} \operatorname{lnGDPC}_{\mathrm{jt}}+\beta_{2} \operatorname{lnPOP}_{\mathrm{jt}}+\beta_{3} \operatorname{lnEDIST}_{\mathrm{ijt}}+$ $\beta_{4} \operatorname{lnRER}_{\mathrm{ijt}}+\beta_{5} \mathrm{CRTBT}_{\mathrm{ijt}}+\beta_{6} \mathrm{CRSPS}_{\mathrm{ijt}}+\mu_{\mathrm{ijt}}$

Where: EXijt (export value of Indonesian tuna to country $\mathrm{j}$ on year $\mathrm{t}$ (million USD)); POPijt (population of importing country $\mathrm{j}$ on year $\mathrm{t}$ (people)); GDPCjt (GDP per capita of importing country $\mathrm{j}$ on year $\mathrm{t}$ (million USD)); EDISTijt (economic distance between exporting country $\mathrm{j}$ and Indonesia $(\mathrm{km})$ ); RER (real exchange rate of Indonesia to importing country $\mathrm{j}$ on year $\mathrm{t}$ ); CR TBTij (coverage ratio TBT imposed by importing country $\mathrm{j}$ on Indonesian tuna on year $\mathrm{t}(\%)$ ); CR SPSijt (coverage ratio SPS imposed by importing country $j$ on Indonesian tuna on year $t(\%))$.

Table 2. Types and sources of data

\begin{tabular}{lcc}
\hline \multicolumn{1}{c}{ Data types } & Sources & Units \\
\hline $\begin{array}{l}\text { NTM (coverage ratio \& } \\
\text { frequency index) }\end{array}$ & I- TIP WTO & $\%$ \\
Population & World Bank & Person \\
GDP per capita & World Bank & Million USD \\
Export value of tuna & WITS & Million USD \\
Economic distance & CEPII & Km*GDP \\
Real exchange rate & World Bank, & Rp/ USD \\
& OECD & \\
IHK & WDI & $\%$ \\
\hline
\end{tabular}




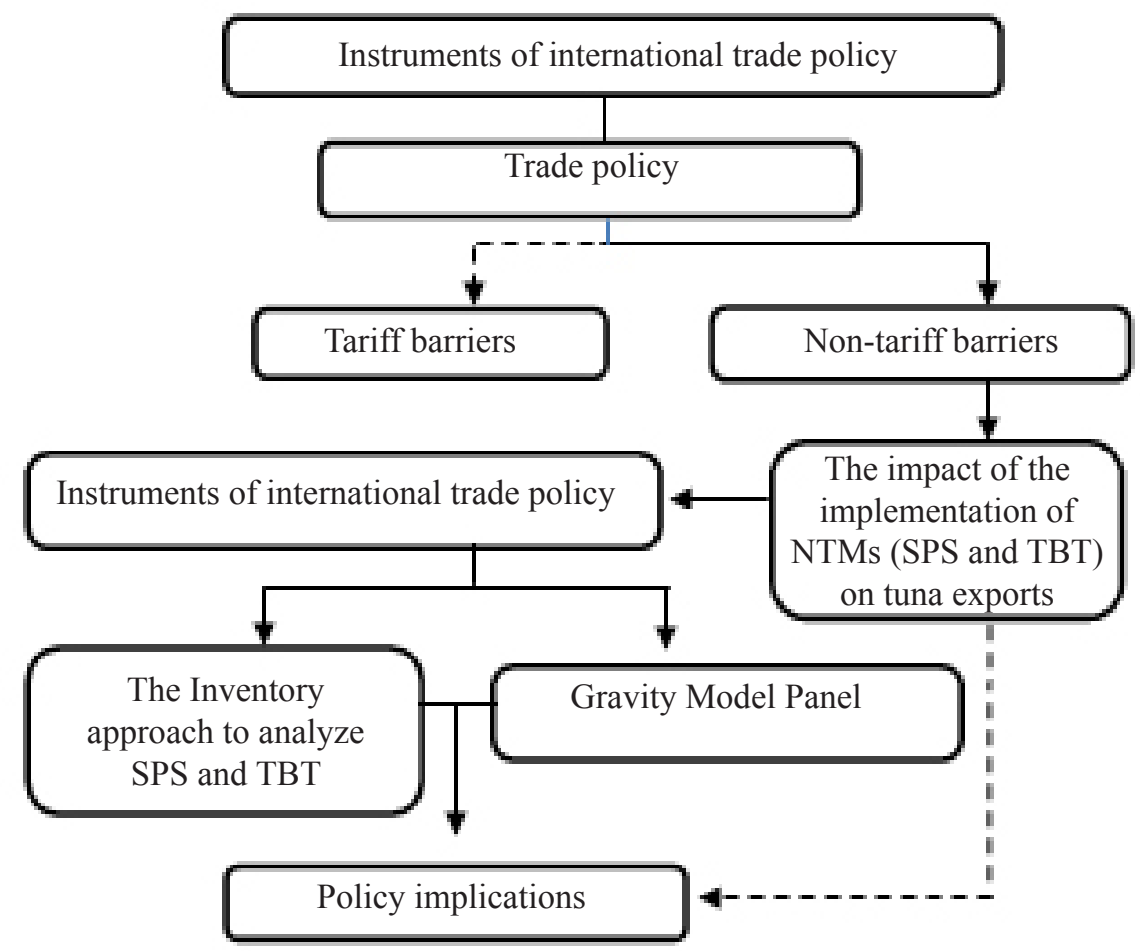

Figure. 1. Research framework

\section{RESULTS}

The results of the research consisted of descriptive analysis and regression analysis gravity model panel data with the dependent variable of the values of Indonesian tuna export to major importer countries such as China, Japan, Thailand, United States, South Korea, Singapore, and Vietnam.

\section{Indonesian Tuna Exports on the Major Destination Countries}

Currently, the trade balance of Indonesian tuna commodities to the major destination countries shows a progress on its performance, making a note of tuna as a potential commodity to encourage the trade balance. Indonesia is the second biggest exporting country for tuna exports and with its marine potency, so there is a huge opportunity to improve its performance.

The illustration shows Japan as the destination country with the highest value of Indonesian tuna exports with 151,151,223.6 million USD in 2013, followed by Thailand with $102,744,769$ million USD, and the United States with 13,406,125 USD (Figure 2). During the period of 2009-2013, the Indonesian tuna exports have been dominated by Japan as the destination country. Japan has a high level of fish consumption that pushes the demand of tuna imports.

The performances of tuna commodities are shown by the trade balance of tuna in the period of 2009-2013 to the destination countries (Table 3). The table shows a surplus in almost all destination countries except for China in 2010-2011 and South Korea in 2013. The deficit in South Korea occurred one in 2013, whereas for the rest of the countries, they had a surplus for their exports.

The deficit of tuna exports to South Korea on 2013 is an impact of the deficit occurred in frozen tuna exports with 5.46 USD and prepared or preserved tuna with 226.08 USD (Table 4). Since 2010, prepared or preserved tuna has always been deficit with an increasing number, so it has decreased the growth of tuna exports. In 2013, the highest surplus for prepared or preserved tuna was $43,674.69$ USD to Japan. The country also had the highest surplus for fresh tuna with 66,390.6 USD, while the frozen tuna had the highest export of $68,933.8$ USD to Thailand. 


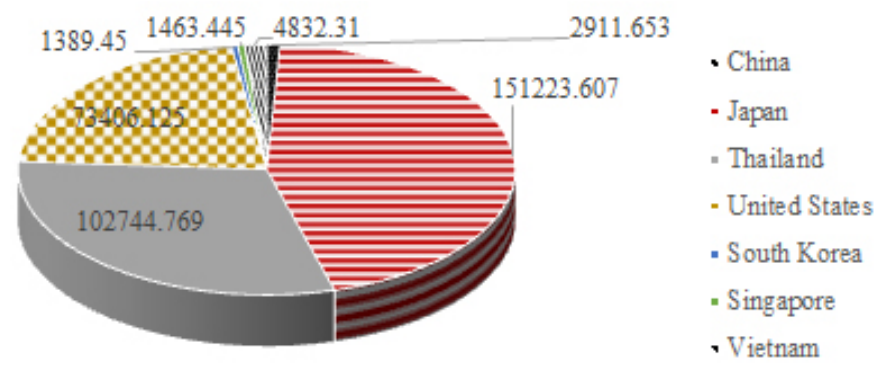

Figure 2. Export values of Indonesian tuna to destination countries in 2013 (000 USD) (UNCOMTRADE, 2015)

Table 3. Trade Balance of Indonesian tuna exports to the Major Destination Countries in 2009- 2013 (000 USD)

\begin{tabular}{|c|c|c|c|c|}
\hline Destination Country & Year & Export & Import & Trade Balance \\
\hline \multirow[t]{5}{*}{ China } & 2009 & $2,411.01$ & $1,388.99$ & $1,022.01$ \\
\hline & 2010 & $1,220.60$ & $3,597.75$ & -2377.16 \\
\hline & 2011 & $1,523.21$ & $8,805.47$ & -7282.26 \\
\hline & 2012 & $5,684.32$ & 607.23 & $5,077.10$ \\
\hline & 2013 & $2,911.65$ & 0.00 & $2,911.65$ \\
\hline \multirow[t]{5}{*}{ Japan } & 2009 & $130,813.28$ & $6,762.34$ & $124,050.94$ \\
\hline & 2010 & $159,927.99$ & $7,956.15$ & $151,971.84$ \\
\hline & 2011 & $174,059.81$ & $17,701.44$ & $156,358.37$ \\
\hline & 2012 & $171,203.43$ & $10,713.49$ & $160,489.95$ \\
\hline & 2013 & $151,223.61$ & $5,125.99$ & $146,097.62$ \\
\hline \multirow[t]{5}{*}{ Thailand } & 2009 & $24,783.09$ & $3,563.49$ & $21,219.60$ \\
\hline & 2010 & $16,293.55$ & $7,847.32$ & $8,446.24$ \\
\hline & 2011 & $36,618.83$ & $6,194.48$ & $30,424.35$ \\
\hline & 2012 & $111,471.01$ & $2,529.82$ & $108,941.20$ \\
\hline & 2013 & $102,744.77$ & $1,149.06$ & 101595.71 \\
\hline \multirow[t]{5}{*}{ United States } & 2009 & $71,382.85$ & 748.86 & $70,633.99$ \\
\hline & 2010 & $75,763.17$ & 122.02 & $75,641.15$ \\
\hline & 2011 & $71,519.46$ & 740.91 & $70,778.55$ \\
\hline & 2012 & $91,619.96$ & 0.00 & $91,619.96$ \\
\hline & 2013 & $73,406.13$ & 106.40 & $73,299.73$ \\
\hline \multirow[t]{5}{*}{ South Korea } & 2009 & $1,503.72$ & 45.97 & $1,457.76$ \\
\hline & 2010 & $2,103.69$ & 158.71 & $1,944.98$ \\
\hline & 2011 & $3,076.24$ & 131.36 & $2,944.88$ \\
\hline & 2012 & $5,181.82$ & 154.05 & $5,027.78$ \\
\hline & 2013 & $1,389.45$ & $1,506.83$ & -117.38 \\
\hline \multirow[t]{5}{*}{ Vietnam } & 2009 & $9,830.67$ & 35.86 & $9,794.81$ \\
\hline & 2010 & $8,940.72$ & 85.68 & $8,855.04$ \\
\hline & 2011 & $7,688.55$ & 58.40 & $7,630.15$ \\
\hline & 2012 & $7,704.51$ & 91.52 & $7,612.99$ \\
\hline & 2013 & $4,832.31$ & 0.00 & $4,832.31$ \\
\hline \multirow[t]{5}{*}{ Singapore } & 2009 & $4,459.90$ & 227.74 & $4,232.16$ \\
\hline & 2010 & $4,409.24$ & 63.18 & $4,346.07$ \\
\hline & 2011 & $1,825.08$ & 12.94 & $1,812.14$ \\
\hline & 2012 & $1,534.37$ & 0.01 & $1,534.36$ \\
\hline & 2013 & $1,463.45$ & 0.00 & $1,463.45$ \\
\hline
\end{tabular}


Table 4. Trade Balance of Indonesian tuna exports on the Major Destination Countries Based on Subgroup in the period of 2010-2013 (000 USD)

\begin{tabular}{llccccc}
\hline \multirow{2}{*}{$\begin{array}{c}\text { Destination } \\
\text { Country }\end{array}$} & \multicolumn{1}{c}{ Subgroup } & \multicolumn{5}{c}{ Year } \\
\cline { 2 - 6 } China & Fresh & 822.66 & 149.32 & 416.16 & 192.80 & 26.85 \\
& Frozen & 152.30 & -2474.57 & -7571.26 & $5,370.14$ & 2718.70 \\
& Prepared or preserved & 47.05 & -51.91 & -127.15 & -485.85 & 166.10 \\
Japan & Fresh & $74,080.88$ & $93,207.11$ & 73746.83 & $61,602.90$ & $66,390.58$ \\
& Frozen & $4,702.77$ & 14288.02 & 26796.88 & $39,455.25$ & $36,032.36$ \\
& Prepared or preserved & $4,5267.29$ & 44476.72 & 55814.66 & $59,431.80$ & $43,674.69$ \\
Thailand & Fresh & $1,814.13$ & 116.56 & 649.65 & 722.40 & 106.47 \\
& Frozen & $1,3417.48$ & -32.21 & $13,321.76$ & $76,341.89$ & $68,933.83$ \\
& Prepared or preserved & $5,987.99$ & $8,361.89$ & $16,452.94$ & $31,876.90$ & $32,555.42$ \\
United & Fresh & $7,984.85$ & $5,778.36$ & $6,249.27$ & $5,037.28$ & $2,653.45$ \\
States & Frozen & $16,104.15$ & $17,660.02$ & $18,740.34$ & $37,249.05$ & $30,342.20$ \\
& Prepared or preserved & 46.545 & $52,202.77$ & $45,788.94$ & $49,333.63$ & $40,304.07$ \\
South & Fresh & 757.07 & 347.75 & 174.58 & 371.39 & 114.35 \\
Korea & Frozen & 695.121 & $1,627.48$ & $2,736.85$ & $4,788.86$ & -5.64 \\
& Prepared or preserved & 5.56 & -30.25 & 33.44 & -132.47 & -226.09 \\
Vietnam & Fresh & $4,12.36$ & 1135.87 & 2179.38 & $1,543.81$ & 95.26 \\
& Frozen & $4,929.42$ & 7352.57 & 5426.67 & $5,822.56$ & $4,737.05$ \\
& Prepared or preserved & 153.03 & 366.60 & 24.09 & 246.61 & 0 \\
Singapore & Fresh & $1,641.36$ & 735.10 & 307.46 & 279.47 & 433.52 \\
& Frozen & $2,325.49$ & $3,369.48$ & $1,329.52$ & 995.90 & 746.96 \\
& Prepared or preserved & 265.30 & 241.48 & 175.15 & 258.98 & 282.95 \\
\hline
\end{tabular}

Source: UNCOMTRADE, 2013 (calculated)

\section{Non-tariff Measures (NTMs) Applied on Indonesian Tuna Exports}

Lately, NTMs have been an important issue in international trade. The tendency of public concerns to product safety and processes related to environment sustainability is the factors why some countries are imposing NTMs in order to improve the national welfare.

SPS and TBT are NTMs that are mostly applied on fisheries subsector. Table 5 shows the number of imposed SPS and TBT by the destination countries for Indonesian tuna exports in the period of 2002-2013. As shown in Table 4, Singapore is the only country who does not impose SPS and TBT. SPS has been more imposed than TBT for most of the destination countries whereas United States has the highest imposed TBT for the tuna exports.

The United States is a destination country that has imposed NTM the most, with 15 SPS measures and 66 TBT measures with a total of 81 measures. The measures of TBT mostly imposed are food standards including 28 measures for production standard processing, and 26 measures for labeling. China is the second country imposing the highest NTMs with the total of 54 measures. Most of SPS measures imposed by China concern with human health, and all the 3 TBT measures imposed are for labeling. Thailand had imposed 44 measures of SPS and 6 TBT measures. Of 40 SPS measures, 38 measures imposed concern about both safety food standard and human health. Japan had imposed 47 measures with 40 measures of SPS, most of which concern with safety food standards, human health, and maximum residue limits (MRLs). SPS and TBT imposed in the destination countries are composed in any measures. The SPS measures imposed the most are safety food standard and human health, while for the TBT measures, they concern with labeling.

\section{Frequency index and Coverage ratio}

The inventory approach is used to measure the NTMs imposed by some countries. It contains a simple measurement using frequency index and coverage 
ratio as the indicators. Frequency index is used to calculate the presence of NTMs and the percentage of the products affected by NTM. Coverage ratio is used to measure the percentage of trade subject affected by NTM on importing countries (Fugazza, 2013; Tilovi 2012; Disdier et al. 2013).

The frequency index in the year of 2009-2013 shows a pretty high number for tuna exports affected by SPS, in the range of $69-100 \%$. Figure 3 shows that Japan, Thailand, and United States have been consistent in imposing SPS on tuna commodities for five years. SPS was imposed in Japan in 2010 at $69.14 \%$ and reached at $82.46 \%$ in 2013 . Thailand has a fluctuated trend of SPS imposed, where it went down at $76.43 \%$ and went up again at $100 \%$ point in 2013 . The United States imposed the SPS consistently at $100 \%$ point in 2010,2012 , and
2013. South Korea had a very sharp fluctuated value, where SPS was imposed the most in 2009, 2011, and 2013 at $97.75 \%, 98.13 \%$, and $99.6 \%$ respectively whereas in 2010 and 2012 no SPS was imposed.

Figure 4 shows that the value of the frequency index of TBT is lower than that of SPS. Thailand and United States happened to be the countries that consistently imposed TBT in the period of 2010-2013. In five years, China only imposed TBT for two years, at $99.18 \%$ in 2010 and $98.58 \%$ in 2011 . The highest number of TBT imposed by Thailand was in 2012 reaching $100 \%$ point. For the United States, there was an increasing value from $22.67 \%$ in 2010 to $31.45 \%$ in 2013 whereas the rest of the destination countries such as Japan, South Korea, and Vietnam had not imposed TBT measures for Indonesian tuna exports.

Table 5. Applied of NTMS'SPS and TBT on Indonesian tuna exports to major destination countries in the period of 2002-2013

\begin{tabular}{lccc}
\hline \multicolumn{1}{c}{ Country } & SPS & TBT & Total \\
\hline China & 51 & 3 & 54 \\
Japan & 40 & 7 & 47 \\
United States & 15 & 66 & 81 \\
Thailand & 44 & 6 & 50 \\
South Korea & 11 & 13 & 24 \\
Vietnam & 2 & 0 & 2 \\
Singapore & 0 & 0 & 0 \\
Total & 163 & 95 & 258 \\
\hline
\end{tabular}

Source: WTO (2015)

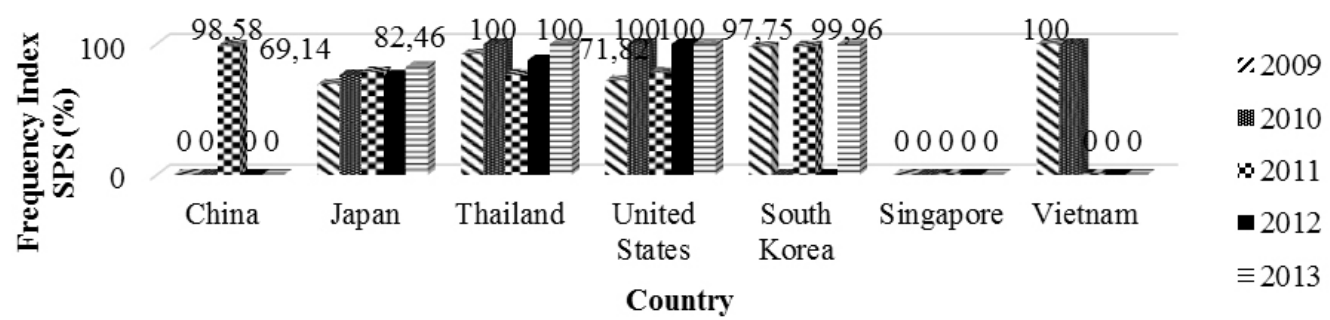

Figure 3. Frequency index SPS on Indonesian tuna exports to destination countries in the period of 2009-2013

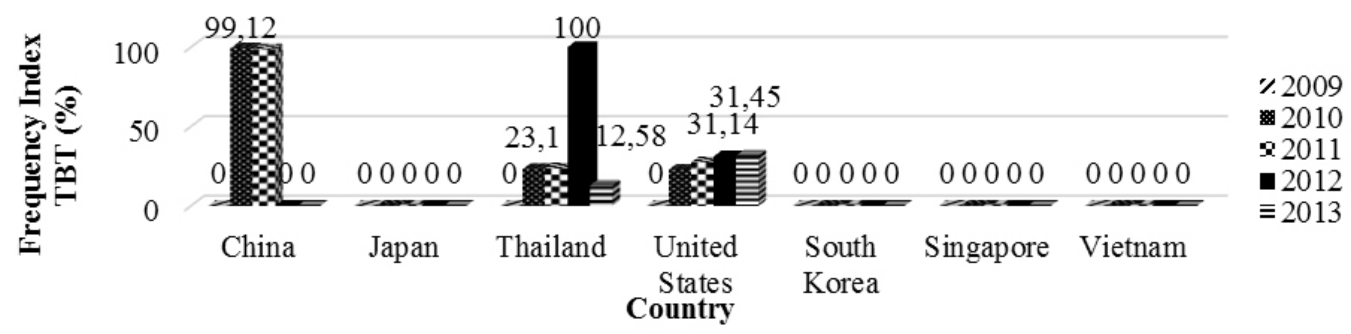

Figure 4. Frequency index TBT on Indonesian tuna exports to destination countries in the period of 2009-2013 
The composition of SPS imposed in 2013 as on frequency index of Figure 5 shows uniformity at $100 \%$ for Japan, Thailand, United States, and South Korea. SPS imposed by Thailand and United States on fresh tuna, frozen tuna, and prepared or preserved tuna reached $100 \%$ for the three countries. It is related to the SPS frequency index on tuna commodities in 2013 that reached 100\% point. Both Japan and South Korea had similar characteristics, where the fresh and frozen tuna had $100 \%$ value of SPS frequency index even though they had a different value in the total frequency index.

Figure 6 shows the composition of TBT in 2013. Figure 3 shows that the TBT was only imposed by Thailand and United States, so only the values of both appeared in the graph. Japan had imposed only TBT for prepared or preserved tuna whereas United States had imposed TBT on fresh and frozen tuna. The other indicator used in inventory approach was coverage ratio. A higher value of coverage ratio shows the higher impact of NTM imposed by destination countries on the importing products. In contrast with frequency index of
SPS that was most likely to be high, the coverage ratio of Indonesian tuna exports had various values in each country.

Based on Figure 7, the SPS was imposed consistently in the United States, Japan, and Thailand in the period of 2009-2013. The highest value of United States occurred in 2010 at $65.24 \%$ but decreased by $64.00 \%$ in 2013. In 2012, Thailand had $46.77 \%$ coverage ratio and increased to $52.28 \%$ in 2013 . South Korea only imposed SPS in 2009, 2011, and 2013 while China had the lowest percentage of SPS in 2011 at $2.19 \%$.

Coverage percentage of Indonesian tuna affected by TBT in the period of 2009-2013 is shown in Figure 8. The United States had a constant increase until $28.86 \%$ in 2013. In 2012, Thailand had a high coverage ratio at $44.81 \%$, as an impact of its higher export value than the previous and the following years whereas Japan, South Korea, and Vietnam did not impose any TBT in the period of 2009-2013.

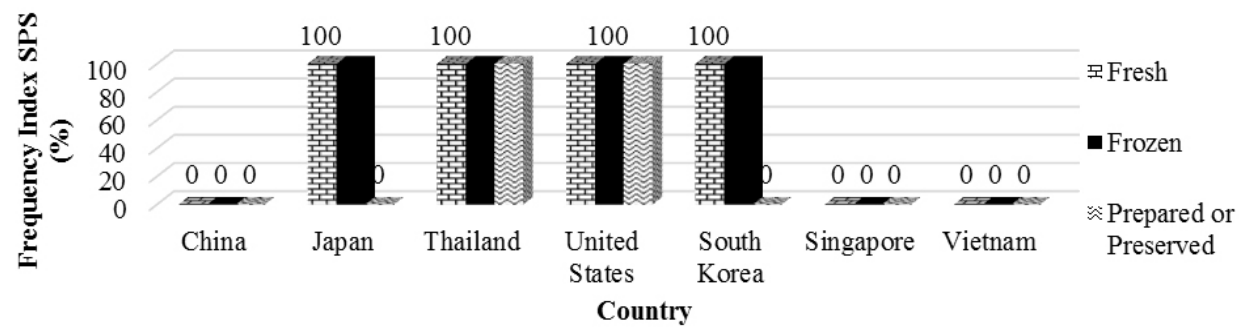

Figure 5. Frequency index SPS on Indonesian tuna exports to destination countries in 2013 according to group commodity

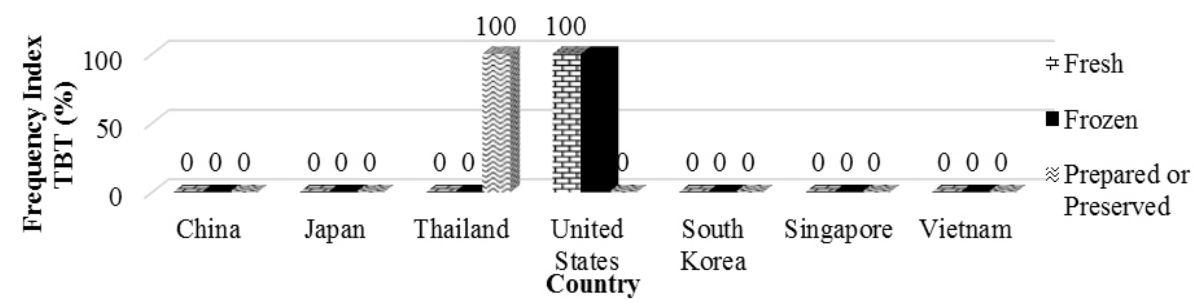

Figure 6. Frequency index TBT on Indonesian tuna exports to destination countries in 2013 according to group commodity

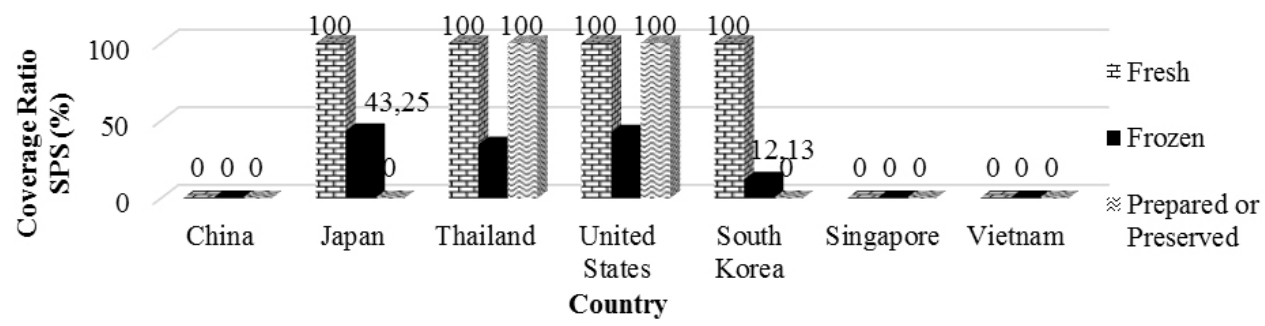

Figure 7. Coverage Ratio SPS on Indonesian tuna exports to destination countries on year 2009-2013 
The diversity on SPS coverage ratio value specifically is shown by Figure 9. The frozen tuna had a different value for Japan, Thailand, United States, and South Korea. The wider coverage of SPS occurred on United States at $100 \%$ point for both fresh and prepared or preserved tuna and $42.45 \%$ for frozen tuna, and so did Thailand reach $100 \%$ point for fresh and prepared or preserved tuna, and $34.72 \%$ for frozen tuna. Both Japan and South Korea did not impose SPS on prepared or preserved tuna but had $100 \%$ point of coverage on fresh tuna.

Based on the Figures 10, we can conclude that in the period of 2009-2013, every destination country had imposed NTMs except for Singapore. SPS is imposed by most of the destination countries while TBT is only imposed by Thailand and United States on some products of Indonesian tuna exports. United States has a higher value of imposing NTM for both frequency index and coverage ratio. Fresh tuna is the commodity affected the most by NTM, with the frequency index at $100 \%$ on all countries imposing SPS and TBT. The lower value of product affected by NTM is prepared or preserved tuna. The percentage of frequency index shows the high frequency of NTMs imposed by the destinations country on Indonesian tuna exports.

\section{The Impact of NTMs on Indonesian Tuna Exports to the Major Destination Countries}

The impact of NTMs (SPS and TBT) on Indonesian tuna exports is discussed on this section. Impact analysis started from the explanation of gravity model testing to BLUE (Best Linier Unbiased Estimator) estimation and analysis on the factors affecting Indonesian tuna exports. The final step is to analyze the impacts of SPS and TBT with the model result.

\section{Model Testing}

The initial stage of the method is to make an estimation to obtain a model that can explain the factors that affect the export of tuna Indonesia. Estimation was carried out through three model approaches i.e. Pooled Least Square (PLS), Fixed Effect Model (FEM), and Random Effect Model Random Effect Model (REM). The best model determination was conducted through Chow test and Hausman test as shown in Table 6.

Based on Table 6, Chow test results show the probability value of 0.0000 less than the level of real alpha $5 \%$, so there is enough evidence to reject Ho.The FEM model is better used than the PLS model. The result of the Hausman test estimation has a 0.0000 probability that is less than the $5 \%$ real alpha level so that there is sufficient evidence to reject Ho. The FEM model is better used than the REM model. The estimation result of FEM model approach can be seen in Table 7.

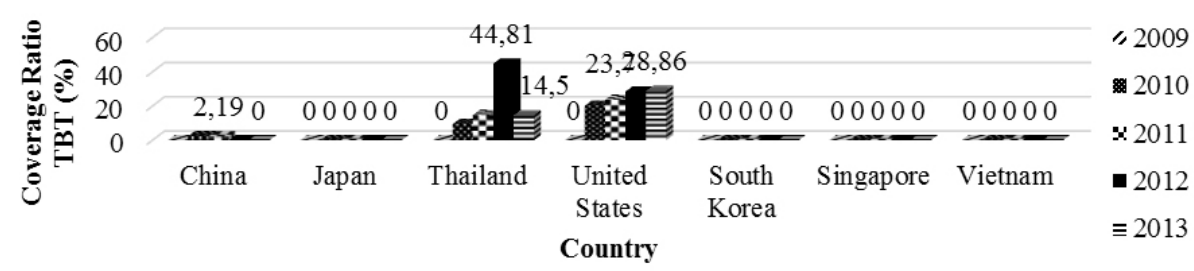

Figure 8. Coverage Ratio of TBT on Indonesian tuna exports to destination countries in the period of 2009-2013

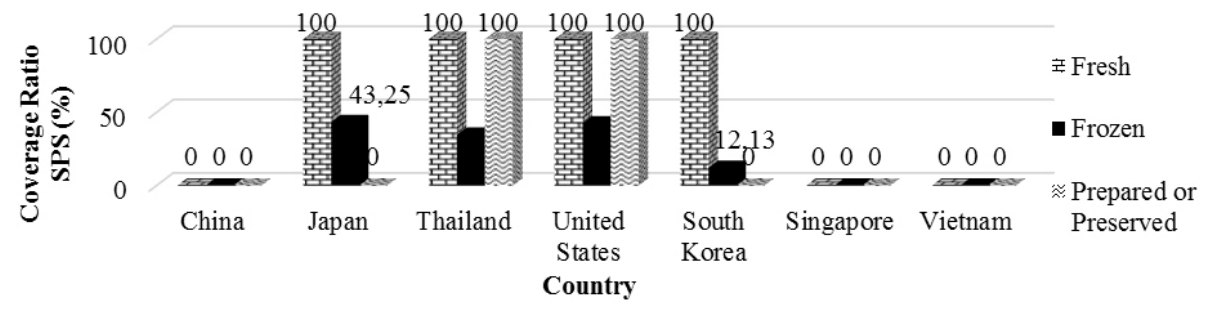

Figure 9. Coverage ratio SPS on Indonesian tuna exports to destination countries in 2013 according to group commodity 


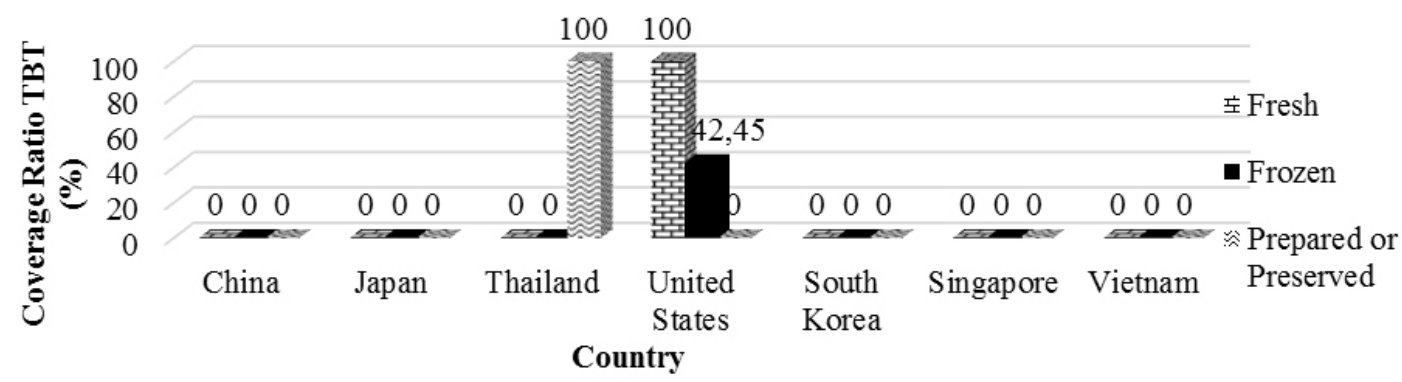

Figure 10. Coverage ratio of TBT on Indonesian tuna exports to destination countries in 2013 based on commodity

Table 6. Test Results Chow and Hausman

\begin{tabular}{lcc}
\hline Best model test & Probabilityy value & Result of the hypothesis \\
\hline Chow test & 0.0000 & Reject H0, than FEM \\
Hausman test & 0.0000 & Reject H0,than FEM \\
\hline
\end{tabular}

Table 7. The Result of Model Estimation of SPS and TBT Impacts

\begin{tabular}{lcc}
\hline \multicolumn{1}{c}{ Variable } & Coefficient & Prob. \\
\hline C & 468.5537 & 0.0000 \\
GDP per capita & $2.363025^{*}$ & 0.0007 \\
Population & $-25.9055^{*}$ & 0.0000 \\
Economic Distance & $-0.9882^{*}$ & 0.0089 \\
Real Exchange Rate & 0.049087 & 0.8623 \\
CR SPS & $0.011215^{*}$ & 0.0048 \\
CR TBT & $0.015269^{*}$ & 0.0136 \\
R-squared & & 0.989646 \\
Prob. (F-statistic) & & 0.000000 \\
\hline
\end{tabular}

The estimation in Table 7 resulted in R-squared at $98.8 \%$. The value means that $98.9 \%$ of Indonesian tuna exports can be explained by the variables of GDP per capita of importing countries, population of importing countries, economic distance between Indonesia and the importing country, coverage ratio of SPS, and coverage ratio of TBT, while the rest of $1.1 \%$ can be explained by other factors outside the model.

\section{Factors Affecting Indonesian Runa Export}

From the estimation in Table 6, there were some variables affecting Indonesian tuna exports. The factors include the GDP per capita of importing countries, population of importing countries, economic distance, and NTMs in the measures of coverage ratio of SPS and TBT. The GDP per capita of importing countries represents the purchasing power of goods and services in some countries. The estimation resulted in alpha 5\% with the coefficient of 2.363 , indicating that the increase of GDP per capita of an importing country at $1 \%$ will increase Indonesian tuna exports at $2.363 \%$ ceteris paribus. Based on the economic theory, GDP per capita has a positive relation to bilateral trade. The increase of GDP per capita of an importing country will increase an absorption capacity that pushes the import demand. The model result is consistent with the hypothesis and the theory.

The population ofimporting countries significantly affects the tuna exports at alpha $5 \%$ with a negative coefficient. It indicates that a decrease at $1 \%$ on importing countries' population will increase the Indonesian tuna exports at $25.9 \%$ ceteris paribus. This condition is contrast with the hypothesis and economic theory which explains that the population of importing countries positively affects the export value. The result on this study is similar that of Tilova (2013) that there is a negatively significant effect of population of importing country on the export value. The contrast result is caused by the tuna commodities used more for raw materials on manufacturing industry than for consumption. Most of the destination countries 
for Indonesian tuna exports are the exporting country of prepared or preserved tuna with a large share such as China, Vietnam, and Thailand. These countries had proceeded the Indonesian fresh tuna to be reexported to other importing countries. Besides, there is substitution consumption for tuna such as salmon that causes a negative coefficient. For Japan only, there is a supposition of decreasing level of consumption as the impact of the changing composition of population that is dominated by adults and elderly. These have given a significant impact to the variable of population on the model with Japan as the first major destination country in the period of 2009-2013.

The variable of economic distance indicates export cost (transportation cost) spent on trading activities. The estimation results show that the economic distance has a significant effect at alpha $5 \%$ with a negative coefficient at 0.988 . It means that the further distance from the destination countries at $1 \%$ will decrease the value export at $0.988 \%$ ceteris paribus. The negative coefficient is consistent with the gravity theory where the distance affects the interaction of two objects. The further the distance is, the higher the transportation cost is for the trading commodities. The increase on transportation cost then will cause a decrease on export value of Indonesian tuna commodities to the major destination countries.

For real exchange rate variable, the result shows a negative coefficient with the probability of more than alpha $5 \%$. It means that real exchange rate of rupiah to importing countries' exchange rate has not significantly affected the Indonesian tuna exports. This result is similar to the studies by Dahar (2014), Fridhowati and Asmara (2013) and Nakakeeto (2011). This could be explained because the major destination countries for Indonesian tuna exports are mostly categorized as countries with high income. A shock on exchange rate will not affect the society's purchasing power on imported products.

The estimation results are consistent with the hypothesis of this study that NTMs affect the Indonesian tuna export values. The NTM impacts were measured by coverage ratio approach for both SPS and TBT. The coverage ratio of SPS and TBT on the models shows a significant effect of alpha $5 \%$ with the positive coefficient at 0.011 and 0.015 . It means that an increase in coverage ratio occurs at $1 \%$ will increase the Indonesian tuna exports at the point of $0.011 \%$ and $0.015 \%$.

\section{Impact Analysis of the Major Destination Countries' NTMs on Indonesian Tuna Exports}

NTMs imposed by some countries are based on some factors related to economic issues, environment, or health. They are imposed in order to protect the society to ensure the welfare and improve the prosperity of a country. SPS and TBT are the import measures being imposed on various sectors in WTO countries, including Indonesia.

SPS measure protects the lives of humans, animals, and plants, health, and environment, while TBT is applied to handle technical regulations and conformity assessment procedures (Fugazza, 2013). The WTO regulation allows the imposition of SPS and TBT if it is based on important reasons related to protection, health, and safety for human, animal, plant, and environment. The regulation is also allowed to improve quality, packaging, labeling, and product standard.

Both coverage ratios of SPS and TBT on the models show the significant effects of alpha $5 \%$ with the values of 0.011 and 0.015 respectively. It means that SPS and TBT are affecting the Indonesian export commodities in spite of the low elasticity value. The positive coefficient for both variables shows that the imposition of SPS and TBT does not always negatively affect trade. SPS positive result on the coverage ratio is similar to that of the study by Crivelli and Groschl (2012). It is undeniable that imposition of SPS will provide information to consumer on the safety of the products. If the SPS measured affects more than the increasing trade cost, the share of consumer market will increase. This increase of share market will make an impact through increasing volume of trade for the producers who manage to overcome the fixed cost for entering the market.

The positive coefficient of TBT is also similar to the result of the study by Shah and Ali (2014). The technical regulation had encouraged the exchange of goods through compatibility increases and product utility. Furthermore, the imposition of TBT had improved the consumers' welfare through implementation of safety standard and food safety. The study by Josling et al. (2008) in Streamlining Non-Tariff Measures: Toolkit for Policy Maker states that the quality standard and labeling have positive impacts on volume and coverage export, while certification procedure has a negative impact. The positive impact occurred through the 
decrease of uncertainty and increase in the consumer's willingness to pay as an impact of increasing quality standard. Furthermore, the standard has ensured the compatibility of a product and decreased the coordination failure between producers. On other side, the needs of checking and certification procedure affect the increasing trade cost.

The importance of NTMs can be known through its impact on the international trade. The results that show a positive value on both measures have proven that Indonesian has been able to meet the standard and regulation applied by the major countries of Indonesian tuna exports. It is believed to be related to the role of tuna Associations to support the development of Indonesian tuna industrial. The existence of the Associations such as ASTUIN, ATLI, and AP2HI has been able to provide the facility (such as armada and after fishing units) and the modal to support an easier access for the producer so that they can be able to suppress the increasing trade cost as the impact of meeting the importing countries' standards. Furthermore, the participation of Indonesia in many international Associations is also affecting the bargaining power and share market on international trade to be able to compete and being one of the biggest tuna exporters of the world.

\section{Managerial Implications}

The positive impact of NTMs shows Indonesia as one of the tuna producers that has been able to manage its trade barriers. The tuna producers, in participation of various associations, have been able to maximize the potency through utilization and suppression of the trade cost and to change NTMs into opportunities. To see this phenomenon, the government is expected to give its full supports by providing easy access for quality and health certification, completing the supporting facilities for pre-process and post-process with additional incentives (special incentives to increase export and additional incentives for selected machinery and equipment), conducting deregulation by reducing the regulatory barriers such as limit entry, limit input, or limit market to create the conducive business situation (this will decrease the price and improve quality and innovation), maximizing the tuna processing industry to improve the product competitiveness through revitalization of fishery product processing industry; and conducting an intensive socialization in order to improve the quality of human resources in fisheries according to the international standards of STCW-F (Standards Training Certification and Watch-keeping for Fisheries).

\section{CONCLUSIONS AND RECOMMENDATIONS}

\section{Conclusions}

Based on the explanations on the previous sections, a number of conclusions can be drawn. Firstly, Indonesian tuna trade in 2009-2013 shows a good performance as can be seen from the positive balance trade. The frozen tuna is the commodity to be exported the most, and the biggest export flows go to Japan. Secondly, SPS and TBT by the major destination countries are imposed in all tuna commodities. Based on the coverage ratio and frequency index values, fresh tuna is the commodity affected the most. The NTM mostly applied is SPS and the United States as the major destination country imposes NTMs (SPS and TBT) the most. Thirdly, GDP per capita of importing country, the population of importing country, and economic distance are the factors affecting Indonesian tuna exports. Real exchange rate has no significant effects. SPS and TBT measured by the coverage ratio approach are significantly affecting Indonesian tuna exports to the major destination countries with the coefficient values of 0.011 and 0.015 respectively.

\section{Recommendations}

It is recommended to conduct research with a longer and new data time range and tuna commodities analyzed are separated based on more specific criteria. In this study tuna commodity which was analyzed consisted of fresh tuna, frozen tuna and processed tuna in the analysis in one model. Three models should be made, namely the fresh tuna model consisting harmony system of 030231, 030232, 030233, 030239, 030240, 030250 and the frozen tuna models consisting of 030241, 030242, 030243, 030249 and the procested tuna models consisteng of 160414. Separated into three categories that have differens behaviors, the model will be specific and profound. 


\section{REFERENCES}

Adi W. 2007. Government Policy in the Application of Ekolabel for the Improvemen of Competitiveness of Indonesian Export Commodities. Jakarta: LIPI.

Beghin JC, Maertens M, and Swinen J. 2015. NonTariff Measures and Standards in Trade and Global Value Chains. Bioeconomics Working Paper Series. Belgium: University of Leuven; 2015.

Boza S. 2013. Sanitary, Phytosanitary, and Technical Measures in Agri-food Trade. Chile: University of Chile.

Bora BA, Kuwahara SLaird. 2002. Quantification of Non-Tariff Measures. Policy Issues In International Trade And Commodities. No 18.

Cadot O, Malouche M, Saez S. 2014. Streamlining Non-Tariff Measures: A Toolkit for Policy Maker. Washington DC: The World Bank.

Criveli P, Groschl J. 2012. The Impact of Sanitary and Phytosanitary Measures on Market Entry and Trade Flows. Working Paper 2012.

Dahar D. 2014. Impact of analysis policy non tariff measures on the performance of export horticulture Indonesia to the country ASEAN +3. Economic development. Scientific magazine. 8(1): 98-116.

Deardorff Alan and Robert Stern. 1998. The Measurement of Non-Tariff Barriers. OECD. Economics Department Working Papers. No. 179.

Disdier AC, Fontagné L, Mimouni M. 2008. The Impact of Regulations on Agricultural Trade: Evidence from the SPS and T BT Agreements. American Journal of Agricultural Economics 90(2): 336-350. https://doi.org/10.1111/j.14678276.2007.01127.x.

Fridhowati N, Asmara A. 2013. Impact of Asean's Non Tariff Measures on Indonesian Electronics Trade. Bulletin of Scientific R and D Trade 7(2): $249-265$.

Fugazza M. 2013. The Economical Behind Non-tariff Measures: Theoritical Insights and Empirical Evidence. Geneva: UNCTAD.
Fontagne L, Mimouni M, Pasteels JM. 2005. Estimating The Impact of Environmental SPS and TBT on International Trade. Geneva: International Trade Center (UNCTAD-WTO).

Henson S, Jaffee S. 2014. Understanding developing country strategic responses to the enhancement of food safety standards. The World Economy 31(4): 548-568. https://doi.org/10.1111/j.14679701.2007.01034.x.

Josling T, Roberts D, Orden D. 2004. Food Regulation and Trade: Towards a Safe and Open Global System. Washington DC: Institute for International Economics.

Ministry of Marine Affairs and Fisheries. 2012. Marine and Fisheries in Item 2012. Jakarta: KKP.

Mufidah L. 2014. The affect the export volume of cinnamon Indonesian to export destination lasgest [thesis]. Bogor: Bogor Agricultural University.

Nakakeeto G. 2011. The impact of technical measures on agricultural trade: a case of Uganda, Senegal, and Mali. improving food security through agricultural trade [thesis]. Blacksburg: Virginia Polytechnic Institute and State University.

Renita A. 2015. Analysis of the effect of non tariff policies on the export of Indonesian $\mathrm{CPO}$ commoditiess to major the countries. Thesis. Bogor Agricultural University. Bogor.

Shah A, SM. Ali. 2014. The Impact of Technical Barrier to Trade on Pakistan Industry. Pakistan Science Journal 66.

Staiger RW. 2012. NonTariff Measures and the WTO. Staff Working Paper for WTO's World Trade Report. Geneva.

Tilova R. 2012. Analysis factors affecting demand Indonesian coal in four country of export the largest [thesis]. Bogor: Bogor Agricultural University.

[UNCTAD] United Nations Conference on Trade and Development. 2013. Non Tariff Measures to Trade: Economic and Policy Issues for Developing Countries. Switzerland. Geneva.

Winchester N. 2008. Is There A Dirty Little Secret? Non-tariff Barriers and The Gains from Trade. University of Otago Economics Discussion Papers No. 0801. 